BARROS, Renata Furtado; MACHADO, José Alberto Oliveira de Paula. Da autonomia a universalização do acesso à justiça: a narrativa da Defensoria Pública pelas Emendas Constitucionais. Revista Eletrônica Direito e Política, Programa de Pós-Graduação Stricto Sensu em Ciência Jurídica da UNIVALI, Itajaí, v.13, n.1, $1^{\circ}$ quadrimestre de 2018. Disponível em: www.univali.br/direitoepolitica - ISSN 1980-7791

\title{
DA AUTONOMIA A UNIVERSALIZAÇÃO DO ACESSO À JUSTIÇA: A NARRATIVA DA DEFENSORIA PÚBLICA PELAS EMENDAS CONSTITUCIONAIS
}

\author{
FROM THE AUTONOMY TO THE UNIVERSALIZATION OF ACCESS TO \\ JUSTICE: THE NARRATIVE OF THE PUBLIC DEFENSE OFFICE BY THE \\ CONSTITUTIONAL AMENDMENTS
}

\section{Renata Furtado Barros ${ }^{1}$}

José Alberto Oliveira de Paula Machado²

\begin{abstract}
SÚMARIO: Introdução; 1. A assistência judiciária a assistência jurídica: breve histórico; 2. Acesso à justiça como direito humano e como desenvolvimento; 3. Assistência jurídica: modelos; 4. Defensoria Pública e suas reformas constitucionais; 4.1 . O projeto do Constituinte Originário; 4.2 Emenda no 45/2004: autonomia das Defensorias Públicas estaduais; 4.3 Novos e velhos desafios com a emenda no 80/2014; Considerações Finais; Referência das fontes citadas.
\end{abstract}

\section{RESUMO}

O presente artigo tem como objetivo abordar as reformas constitucionais da Defensoria Pública e os seus respectivos êxitos em atingir um modelo efetivo de assistência jurídica integral gratuita. A pesquisa será predominantemente empírica com abordagem quantitativa de dados auferidos dos Diagnósticos da Defensoria Pública no Brasil publicado pelo Ministério da Justiça no ano de 2004, 2006, 2009 e 2015. De forma complementar, contemplou-se o método dedutivo e a realização de análise bibliográfica a partir de fontes diversas de informações. Concluiu-se que a opção política por um serviço público de qualidade ganha força e legitimidade a cada dia, entretanto a projeção do cumprimento do projeto constitucional de assistência jurídica gratuita em todas as comarcas ressalta um cenário desafiador para a maioria dos Estados brasileiros.

Palavras-chave: Acesso à Justiça; Defensoria Pública; Desenvolvimento; Direitos Humanos; Emendas Constitucionais

1 Doutora em Direito Público pela PUC Minas; Mestre em Direito Público pela PUC Minas; Professora de Direito Constitucional e Internacional Concursada da PUC Minas. Email: renatafbarros@gmail.com

2 Mestrando em Direito Econômico e Desenvolvimento, pelo Pontifícia Universidade Católica do Paraná PUC/PR; Defensor Público do Estado de Rondônia. Email: jose.machado@defensoria.ro.def.br 
BARROS, Renata Furtado; MACHADO, José Alberto Oliveira de Paula. Da autonomia a universalização do acesso à justiça: a narrativa da Defensoria Pública pelas Emendas Constitucionais. Revista Eletrônica Direito e Política, Programa de Pós-Graduação Stricto Sensu em Ciência Jurídica da UNIVALI, Itajaí, v.13, n.1, 10 quadrimestre de 2018. Disponível em: www.univali.br/direitoepolitica - ISSN 1980-7791

\section{ABSTRACT}

This article aims to address the constitutional reforms of the Public Defender's Office and their respective successes in achieving an effective model of legal aid. The research will be predominantly empirical with a quantitative approach to data obtained from the Public Defender's Diagnostics in Brazil published by the Ministry of Justice in the years of 2004, 2006, 2009 and 2015. In a complementary manner, the deductive method and the bibliographic analysis from diverse sources of information. It was concluded that the political option for a quality public service gains strength and legitimacy every day, however the projection of compliance with the constitutional project of legal aid in all regions highlights a scenario that is challenging for most Brazilian states.

Keywords: Access to Justice - Public Defender's Office - Development Human Rights - Constitutional Amendments

\section{INTRODUÇÃO}

Inicialmente, importa apresentar as razões, ainda que breves, da proposta do presente artigo de fazer uma breve retrospectiva do projeto constitucional da Defensoria Pública a partir das Emendas Constitucionais e de dados quantitativos diagnosticados pelo Ministério da Justiça nos últimos quinze anos.

Consigna-se que a criação da Defensoria Pública está diretamente relacionada à evolução histórica do modelo de assistência jurídica gratuita prestada pelo Estado aos necessitados. A partir do momento em que o Estado é instado a garantir o acesso à justiça via concessão de benefícios de isenção de taxas e custas judiciárias, surge também um múnus público que visa a garantir a orientação e defesa jurídica à população carente.

A prestação de um serviço jurídico e gratuito à parcela necessitada da população demandou, na história republicana do Brasil, a necessidade de estruturação de um órgão estatal com função e atributos próprios para prestar adequadamente a assistência jurídica integral.

Dessa forma, os primeiros capítulos apresentaram esse histórico de implantação da assistência judiciária e de seus modelos até sua alteração para o conceito de assistência jurídica integral como forma de atender os diversos enfoques do acesso à justiça. 
BARROS, Renata Furtado; MACHADO, José Alberto Oliveira de Paula. Da autonomia a universalização do acesso à justiça: a narrativa da Defensoria Pública pelas Emendas Constitucionais. Revista Eletrônica Direito e Política, Programa de Pós-Graduação Stricto Sensu em Ciência Jurídica da UNIVALI, Itajaí, v.13, n.1, $1^{\circ}$ quadrimestre de 2018. Disponível em: www.univali.br/direitoepolitica - ISSN 1980-7791

Por fim, o artigo dedicou-se a expor cronologicamente as Emendas Constitucionais que regularam a Defensoria Pública e suas implicações no perfil institucional e no desafio do acesso à justiça em um país de desigualdade social.

A metodologia é predominantemente empírica com abordagem quantitativa de dados auferidos do I, II, III, e IV Diagnóstico da Defensoria Pública no Brasil publicado pelo Ministério da Justiça no ano de 2004, 2006, 2009 e 2015, respectivamente. De forma complementar, contemplou-se o método dedutivo e a realização de análise bibliográfica a partir de fontes diversas de informações, com o objetivo de contextualizar e aprimorar a construção dos instrumentos de coleta de dados.

\section{A ASSISTÊNCIA JUDICIÁRIA A ASSISTÊNCIA JURÍDICA: BREVE HISTÓRICO}

A criação da Defensoria Pública como instituição organizada é, de certa forma, uma ideia recente. No entanto, a consciência de que aos necessitados deve-se garantir o acesso à Justiça e o direito a igualdade, remonta aos tempos mais antigos da sociedade.

Já em Atenas, na Grécia antiga, podemos vislumbrar uma atuação mais concreta junto aos pobres. Nesta região eram designados anualmente dez advogados para defender esses menos favorecidos contra os poderosos diante dos tribunais civis e criminais ${ }^{3}$.

Entretanto, é somente com a Revolução Francesa, em 1789 que o Estado passou a organizar instituições oficiais a fim de prestar assistência judiciária aos carentes. É que, junto com a Revolução Francesa, foi proclamado o Princípio da Igualdade perante a lei, e com esta proclamação adveio a necessidade clara de que ao Estado cabia responsabilizar-se, através de

3 MORAES, Humberto Peña de; DA SILVA, José Fontenelle Teixeira. Assistência Judiciária: Sua Gênese, Sua História e a Função Protetiva do Estado. Rio de Janeiro: Liber Juris, 1984. p.43. 
BARROS, Renata Furtado; MACHADO, José Alberto Oliveira de Paula. Da autonomia a universalização do acesso à justiça: a narrativa da Defensoria Pública pelas Emendas Constitucionais. Revista Eletrônica Direito e Política, Programa de Pós-Graduação Stricto Sensu em Ciência Jurídica da UNIVALI, Itajaí, v.13, n.1, $1^{\circ}$ quadrimestre de 2018. Disponível em: www.univali.br/direitoepolitica - ISSN 1980-7791

instituições organizadas, na forma de serviço público, em favor de uma suposta igualdade jurídica.

Digno de nota que um dos pioneiros da noção dogmática de serviço público foi o ilustre autor francês Léon Duguit, atento a questão da legitimação do Estado em sua crescente intervenção em setores antes reservados à atividade privada ${ }^{4}$.

Isso porque a substituição do velho regime francês pelo Estado Republicano, paulatinamente criou uma nova relação entre os cidadãos e a Administração Pública, em que o Estado passou a se apresentar de fato, menos sob a forma de manifestações de autoridade (puissance public), do que como um prestador de serviços (service public), cujo objetivo é de satisfazer o melhor possível às necessidades do público.

Não é por outro motivo que, sob o ideário de igualdade da Revolução Francesa e da Declaração dos Direitos do Homem e do Cidadão em 1789, a França aprovou em 22 de janeiro de 1851 o primeiro "Código de Assistência Judiciária" da história, que de vanguarda manifestava na exposição de motivos a inquietação com o acesso à justiça para a população sem renda:

A igualdade dos cidadãos perante a lei, tão justamente proclamada por todas as constituições e declarações, é, infelizmente, apenas uma palavra vazia de sentido do ponto de vista do homem que esteja sem condição de preencher os requisitos necessários para invocar o amparo das leis e dirigir-se regularmente a seus órgãos. Dizer a alguém: 'Você não poderá apresentar sua demanda (causa), mesmo sendo ela justa'; ou dizer-lhe: 'Você não poderá apresentá-la a menos que desembolse uma certa quantia em dinheiro, que você não possui'; é, na realidade, a mesma coisa; não há diferenças que do ponto de vista da teoria, do ponto de vista da prática não há nenhuma diferença ${ }^{5}$.

4 GROTTI, Dinorá. O serviço Público e a Constituição Brasileira de 1988. São Paulo: Malheiros Editores, 2003. p.119.

5 ALVES, Cleber Francisco. Justiça para Todos! Assistência Jurídica Gratuita nos Estados Unidos, na França e no Brasil. Rio de Janeiro: Lumen Juris, 2006. p.165. 
BARROS, Renata Furtado; MACHADO, José Alberto Oliveira de Paula. Da autonomia a universalização do acesso à justiça: a narrativa da Defensoria Pública pelas Emendas Constitucionais. Revista Eletrônica Direito e Política, Programa de Pós-Graduação Stricto Sensu em Ciência Jurídica da UNIVALI, Itajaí, v.13, n.1, 10 quadrimestre de 2018. Disponível em: www.univali.br/direitoepolitica - ISSN 1980-7791

Não se pode deixar de reconhecer o pioneirismo da França no que diz respeito à construção do conceito moderno de assistência e representação gratuita dos pobres em juízo, com a superação do modelo originário estritamente caritativo ${ }^{6}$.

No Brasil, por sua vez, a origem da Defensoria Pública remonta as Ordenações Filipinas ${ }^{7}$, gênese da assistência judiciária, conforme adverte o Defensor Público do Estado do Rio de Janeiro, José Fontenelle Teixeira da Silva:

Em nosso País, as origens mais remotas da Defensoria Pública estão nas Ordenações Filipinas, que vigoram, no Brasil, até finais de 1916, por força da Lei de $2^{\circ}$ de outubro de 1823. De fato, no Livro III, Título 84, § 10. aquelas ordenações prescreviam, aos dizeres da época, o que, hoje, denominamos afirmação de pobreza, verbis: "§ 10 - Em sendo o agravante tão pobre que jure não ter bens móveis, nem de rais, nem por onde pague o aggravo, e dizendo na audiência uma vez o Pater Noster pela alma Del Rey Don Diniz, ser-lhe-á havido, como se pagasse os novecentos réis, contanto que tire de tudo certidão dentro do tempo, em que havia de pagar o aggravo"8.

Inexistia uma instituição no período imperial destinada a prestação da assistência jurídica aos pobres. A primeira Constituição Republicana, de 24 de fevereiro de 1891, também não elevou a assistência judiciária à matéria constitucional, mantendo-se omissa sobre o assunto. No entanto, essa

6 ALVES, Cleber Francisco. Justiça para Todos! Assistência Jurídica Gratuita nos Estados Unidos, na França e no Brasil. p.170.

7 No mesmo sentido Celso Ribeiro Bastos: "no Brasil, a assistência judiciária tem suas raízes nas Ordenações Filipinas. Esse diploma foi muito importante na história do Brasil porque, por força da Lei de 20 de outubro de 1823, vigorou por estas terras até 1916. Com o passar dos anos, a incumbêcia vai gradativamente recaindo nos ombros da classe dos advogados, coisa que não era estranha às idéias reinantes, de há muito, nas corporações de causídicos" BASTOS, Celso Ribeiro Bastos. Comentários à Constituição do Brasil. $1^{\text {a }}$ ed. São Paulo: Saraiva, 1989. p.374.

8MORAES, Humberto Peña de; DA SILVA, José Fontenelle Teixeira. Assistência Judiciária: Sua Gênese, Sua História e a Função Protetiva do Estado. p.57. 
BARROS, Renata Furtado; MACHADO, José Alberto Oliveira de Paula. Da autonomia a universalização do acesso à justiça: a narrativa da Defensoria Pública pelas Emendas Constitucionais. Revista Eletrônica Direito e Política, Programa de Pós-Graduação Stricto Sensu em Ciência Jurídica da UNIVALI, Itajaí, v.13, n.1, 10 quadrimestre de 2018. Disponível em: www.univali.br/direitoepolitica - ISSN 1980-7791

Carta no artigo $72^{\circ}, \S 16^{\circ}$, já fazia alusão à uma plena defesa que deveria realizar-se com todos os recursos e meios essenciais a ela.

A prestação da assistência judiciária tornou-se matéria constitucional a partir da Carta Política de 1934, governo de Getúlio Vargas, que apresentou como característica a constitucionalização dos direitos sociais com a criação do mandado de segurança e da ação popular e notadamente inaugurou no Título III, Capítulo II, artigo 1130, nº. 32 na história das constituições brasileiras o direito de acesso gratuito à Justiça: "A União e os Estados concederão aos necessitados assistência judiciária, para esse efeito, órgãos especiais, e assegurando isenção de emolumentos, custas, taxas e selos." ${ }^{\prime 9}$

Para José Carlos Barbosa Moreira:

(...) a norma de 1934 tratava de um conjunto de duas ordens de providências: "isenção de emolumentos, custas, taxas e selos" e a criação imposta à União e aos Estados, de "órgãos especiais" para assistir aos necessitados. Cuidava de duas dimensões realmente distintas e complementares, quais sejam, a dispensa do pagamento das custas judiciárias e a prestação gratuita de serviços jurídicos, respectivamente, a Justiça Gratuita e a Assistência Judiciária. ${ }^{10}$

Em 10 de novembro de 1937 com um golpe liderado pelo próprio Presidente Getúlio Vargas, inicia-se o Estado Novo que iria durar até 1945. Neste período conturbado foi outorgada a Constituição de 1937, denominada de Constituição Polaca, que apresentou como característica principal a redução da esfera dos direitos individuais, excluindo a previsão da assistência

9 BRASIL. Constituição (1934). Constituição da República dos Estados Unidos do Brasil (1934). Brasília: Casa Civil, s.d. Disponível em: <https://www2.senado.leg.br/bdsf/bitstream/handle/id/137569/Constituicoes_Brasileiras>. Acesso em: 27/04/2017.

10 MOREIRA, José Carlos Barbosa. O Direito à Assistência Jurídica: Evolução no ordenamento brasileiro de nosso tempo. Revista da Academia Brasileira de Letras Jurídicas, n.3, ano VI, Rio de Janeiro: Renovar, 1992. Disponível em: <http://www.ablj.org.br/revistas/revista3/revista3\%20JOSE\%20CARLOS\%20BARBOSA\%20 MOREIRA\%200\%20direito\%20\%C3\%A0\%20Assist\%C3\%AAncia\%20Jur\%C3\%ADdica\%20ev olu\%C3\%A7\%C3\%A3o\%20no\%20Ordenamento\%20brasileiro\%20de\%20nosso\%20tempo.p df> Acesso em 25/06/2017. 
BARROS, Renata Furtado; MACHADO, José Alberto Oliveira de Paula. Da autonomia a universalização do acesso à justiça: a narrativa da Defensoria Pública pelas Emendas Constitucionais. Revista Eletrônica Direito e Política, Programa de Pós-Graduação Stricto Sensu em Ciência Jurídica da UNIVALI, Itajaí, v.13, n.1, $1^{\circ}$ quadrimestre de 2018. Disponível em: www.univali.br/direitoepolitica - ISSN 1980-7791

judiciária, a qual retomou sua previsão, mas com natureza infraconstitucional no Código de Processo Civil de 1939 (Decreto-lei no 1.608 , de 18 de setembro de 1939).

"Por sua vez, o parágrafo único do artigo $68^{\circ}$ do Código de Processo Civil ditava que a assistência judiciária seria prestada por advogado escolhido pela parte; caso não o fazendo, seria indicado (defensor) pela assistência judiciária e, na falta desta, nomeado pelo juiz"11.

Percebe-se, pois, que, sob a Constituição Democrática de $1934^{12}$ e o Código de Processo Civil de 1939, qualquer envolvimento do Estado em prestar serviço jurídico gratuito cingia-se à indicação de profissional liberal que atuava pro bono, situação que comprometia a estatização de um serviço de assistência jurídica integral, gratuita e pública, em contrariedade com o dever de constituição de um órgão próprio para aquele mister à época.

Nesse mesmo sentido, aliás, o Código de Processo Penal de 1941, em seus artigos $263^{\circ}$ e $32^{\circ}$, adotou regras segundo as quais, em não tendo o acusado ou o autor da ação penal privada condições de contratar advogado, o juiz Ihe nomearia um ${ }^{13}$.

Apesar do silêncio da Constituição Federal outorgada durante o Estado Novo de 1937, a assistência judiciária volta ao texto da Constituição de 1946:

11 BORGE, Felipe Dezorzi. Defensoria Pública: uma breve história. Revista Jus Navigandi, ISSN 1518-4862, Teresina, ano 15, n. 2480, 16abr. 2010. Disponível em: <https://jus.com.br/artigos/14699>. Acesso em: 19 jun. 2017.

12 Em atenção ao mandamento constitucional o Estado de São Paulo, em 1935, foi o primeiro a adotar o serviço estatal de Assistência Judiciária do Brasil, despido, no entanto, de uma Instituição específica para esta prestação, o qual era realizado pelo Departamento XI de Agosto da Universidade São Francisco.

13 OLIVEIRA, Maria Beatriz Bogado Bastos de. A Defensoria Pública como garantia de acesso à justiça. Revista da Defensoria Pública do Rio de Janeiro, n.16, ano 12: Rio de Janeiro, 2000. p.98. 
BARROS, Renata Furtado; MACHADO, José Alberto Oliveira de Paula. Da autonomia a universalização do acesso à justiça: a narrativa da Defensoria Pública pelas Emendas Constitucionais. Revista Eletrônica Direito e Política, Programa de Pós-Graduação Stricto Sensu em Ciência Jurídica da UNIVALI, Itajaí, v.13, n.1, $1^{\circ}$ quadrimestre de 2018. Disponível em: www.univali.br/direitoepolitica - ISSN 1980-7791

"Artigo 146 ○ §35. O poder público na forma que a lei estabelecer, concederá assistência judiciária aos necessitados ${ }^{14 "}$.

Como vemos o texto assegura aos necessitados essa prestação, a ser concedida pelo Poder Público. No entanto, não especifica quem a prestará: se o Estado ou a União, permanecendo concorrente esta competência.

Essa omissão quanto à competência de quem deverá patrocinar a assistência aos necessitados, assim como, a omissão quanto aos meios de propiciá-la, fez com que cada Estado-membro tomasse posicionamento diante do tema. Vários Estados, a partir de então, criaram órgãos oficiais específicos para a prestação desta assistência. E, outros vários Estados passaram a credenciar advogados especiais para o serviço, sem se deter à criação de órgãos específicos.

O marco legal da garantia do acesso gratuito à justiça no Brasil, deveras, ocorreu em 05 de fevereiro de 1950 quando foi publicada a Lei no 1.060, que regulou a concessão de assistência judiciária aos necessitados, estabelecendo no $\$ 1^{\circ}$ do artigo $5^{\circ}$ que uma vez deferido o benefício da assistência o juiz determinaria ao serviço de assistência judiciária a indicação de advogado a patrocinar a causa do necessitado. A diferenciação com os textos anteriores está na menção expressa de que aludido serviço de assistência judiciária era organizado e mantido pelo Estado. Era a sinalização do dever estatal de formatar uma instituição pública responsável por garantir a assistência judiciária àqueles desprovidos de recursos ${ }^{15}$.

Com o advento da Constituição Federal de 1967 e da Emenda Constitucional de 1969 , respectivamente, os artigos $150^{\circ}, \S 32^{\circ}$ e $153^{\circ}, \S 32^{\circ}$, transferiram

14 BRASIL. Constituição (1946). Constituição dos Estados Unidos do Brasil (1946). Brasília: Casa Civil, s.d Disponível em: <http://www2.camara.leg.br/acamara/conheca/museu/publicacoes/arquivos-pdf/Constituicoes\%20Brasileiras-PDF.pdf> . Acesso em: 27/04/2017.

15 BORGE, Felipe Dezorzi. Defensoria Pública: uma breve história. Revista Jus Navigandi, ISSN 1518-4862, Teresina, ano 15, n. 2480, 16abr. 2010. Disponível em: <https://jus.com.br/artigos/14699>. Acesso em: 19 jun. 2017. 
BARROS, Renata Furtado; MACHADO, José Alberto Oliveira de Paula. Da autonomia a universalização do acesso à justiça: a narrativa da Defensoria Pública pelas Emendas Constitucionais. Revista Eletrônica Direito e Política, Programa de Pós-Graduação Stricto Sensu em Ciência Jurídica da UNIVALI, Itajaí, v.13, n.1, $1^{\circ}$ quadrimestre de 2018. Disponível em: www.univali.br/direitoepolitica - ISSN 1980-7791

para a legislação ordinária a responsabilidade de delinear um paradigma para a assistência judiciária no Brasil, no caso a lei no $1.060 / 50$, pois não revelaram como nas Constituições de 1934 e 1946, se o serviço haveria de ser prestado pelo Estado ou não ${ }^{16}$.

A Constituição do Rio de Janeiro de 1975 em conjunto com a Lei Complementar 06 do Estado do Rio de Janeiro de 1977 inovou o cenário constitucional de época para institucionalizar a assistência judiciária daquele estado já na forma de serviço público da Defensoria Pública, apartando suas atribuições e subordinação ao Chefe do Ministério Público ${ }^{17}$.

Esse modelo de Defensoria Pública como assistência judiciária adotado pela Constituição Estadual do Rio de Janeiro de 1975 foi encampado pela Carta Constitucional de 1988, a qual erigiu nacionalmente a Defensoria Pública à função essencial à Justiça no artigo $134^{\circ}$, oportunidade em que conferiu nova roupagem e ratificou ao Estado o dever de prestar a assistência jurídica integral e gratuita aos que comprovarem insuficiência de recursos, artigo 50, LXXIV.

O marco dessa redemocratização foi que o constituinte abdicou da expressão "assistência judiciária" consagrando em substituição a locução "assistência jurídica integral" no artigo 50, LXXIV, rol de direitos fundamentais:

Diferentemente da assistência judiciária prevista na constituição anterior, a assistência jurídica tem conceito mais abrangente e abarca a consultoria e atividade jurídica extrajudicial em geral. Agora, portanto, o Estado promoverá a assistência aos necessitados no que pertine a aspectos legais, prestando informações sobre comportamentos a serem seguidos diante de

16 BORGE, Felipe Dezorzi. Defensoria Pública: uma breve história. Revista Jus Navigandi, ISSN 1518-4862, Teresina, ano 15, n. 2480, 16abr. 2010. Disponível em: <https://jus.com.br/artigos/14699>. Acesso em: 19 jun. 2017.

17 OLIVEIRA, Maria Beatriz Bogado Bastos de. A Defensoria Pública como garantia de acesso à justiça. Revista da Defensoria Pública do Rio de Janeiro, n.16, ano 12: Rio de Janeiro, 2000. p.105. 
BARROS, Renata Furtado; MACHADO, José Alberto Oliveira de Paula. Da autonomia a universalização do acesso à justiça: a narrativa da Defensoria Pública pelas Emendas Constitucionais. Revista Eletrônica Direito e Política, Programa de Pós-Graduação Stricto Sensu em Ciência Jurídica da UNIVALI, Itajaí, v.13, n.1, 10 quadrimestre de 2018. Disponível em: www.univali.br/direitoepolitica - ISSN 1980-7791

problemas jurídicos, e, ainda, propondo ações e defendendo o necessitado nas ações em face dele propostas $^{18}$.

Um novo enquadramento para uma nova missão que a Defensoria Pública deveria encarar.

\section{ACESSO À JUSTIÇA COMO DIREITO HUMANO E COMO DESENVOLVIMENTO}

Como pode observar, a história do Acesso à Justiça na modernidade se confunde com a evolução do Estado, que já foi detido na mão de uma única pessoa, no Estado absoluto e que passou um processo de reconhecimentos de direitos individuais e coletivos até a consagração dos valores democráticos, especialmente de cidadania ${ }^{19}$.

Isso porque o acesso à justiça é condição fundamental para o exercício da cidadania. Como expressão de todo e qualquer Estado Democrático, o direito ao acesso à Justiça é o reconhecimento da dignidade humana do indivíduo, na medida em que é o pressuposto basilar para a tutela de todos os demais direitos.

Hannah Arendt aclara que o "direito fundamental de cada indivíduo, antes de qualquer dos direitos enumerados em declarações, é o direito a ter direitos, isto é, o direito de pertencer a uma comunidade disposta e capaz de garantir-Ihe qualquer direito ${ }^{20 "}$.

18 NERY JR., Nelson. Princípios do Processo Civil na Constituição Federal. 5. ed. São Paulo: Revista dos Tribunais, 2005. p.77.

19 ALVES, Cleber Francisco. Justiça para Todos! Assistência Jurídica Gratuita nos Estados Unidos, na França e no Brasil. p.76.

20 ARENDT, Hannah. Origens do Totalitarismo - Antissemitismo, Imperialismo, Totalitarismo. Tradução de Roberto Raposo. São Paulo: Companhia das Letras, 1989. p.332. 
BARROS, Renata Furtado; MACHADO, José Alberto Oliveira de Paula. Da autonomia a universalização do acesso à justiça: a narrativa da Defensoria Pública pelas Emendas Constitucionais. Revista Eletrônica Direito e Política, Programa de Pós-Graduação Stricto Sensu em Ciência Jurídica da UNIVALI, Itajaí, v.13, n.1, 10 quadrimestre de 2018. Disponível em: www.univali.br/direitoepolitica - ISSN 1980-7791

Produto do movimento histórico dessa luta pela cidadania, o acesso à justiça tornou-se um direito humano fundamental, reconhecido em diversos tratados internacionais.

A Declaração Americana dos Direitos e Deveres do Homem de 1948 prevê no art. $18^{\circ}$ :

Toda pessoa pode recorrer aos tribunais para fazer respeitar os seus direitos. Deve poder contar, outrossim, com processo simples e breve, mediante o qual a justiça a proteja contra atos de autoridade que violem, em seu prejuízo, quaisquer dos direitos fundamentais consagrados constitucionalmente ${ }^{21}$.

Igualmente prescreve 0 art. $8^{\circ}$ da Declaração Universal dos Direitos Humanos de dezembro do mesmo ano:

Todo ser humano tem direito a receber dos tribunais nacionais competentes remédio efetivo para os atos que violem os direitos fundamentais que Ihe sejam reconhecidos pela constituição ou pela $\operatorname{lei}^{22}$.

Esse compromisso dos Estados com o respeito aos direitos fundamentais, foi ratificado pelo Pacto Internacional de Direitos Civis e Políticos de 1966, com dispositivo consolidando esse compromisso assumido pelos Estados:

Art. 20. 3. Cada Estado Parte no presente Pacto compromete-se a : a. Garantir que todas as pessoas cujos direitos e liberdades reconhecidos no presente Pacto forem violados disponham de recurso eficaz, mesmo no caso de a violação ter sido cometida por pessoas agindo no exercício das suas funções oficiais; b. Garantir que a competente autoridade judiciária, administrativa ou legislativa, ou qualquer outra autoridade competente, segundo a legislação do Estado, estatua sobre os direitos da pessoa que forma

21 DECLARAÇÃO AMERICANA DOS DIREITOS E DEVERES DOS HOMENS. 1948. Disponível em: <https://www.cidh.oas.org/basicos/portugues/b.Declaracao_Americana.htm>. Acesso em: $20 / 04 / 2017$.

22 DECLARAÇÃO UNIVERSAL DOS DIREITOS DOS HOMENS. ONU. 1948. Disponível em: < http://www.ohchr.org/EN/UDHR/Documents/UDHR_Translations/por.pdf>. Acesso em: 20/04/ 2017. 
BARROS, Renata Furtado; MACHADO, José Alberto Oliveira de Paula. Da autonomia a universalização do acesso à justiça: a narrativa da Defensoria Pública pelas Emendas Constitucionais. Revista Eletrônica Direito e Política, Programa de Pós-Graduação Stricto Sensu em Ciência Jurídica da UNIVALI, Itajaí, v.13, n.1, 10 quadrimestre de 2018. Disponível em: www.univali.br/direitoepolitica - ISSN 1980-7791

o recurso, e desenvolver as possibilidades de recurso jurisdicional $^{23}$.

Esses compromissos atestam a ação das sociedades contemporâneas na tentativa de assegurar a relação existente entre justiça, cidadania e desenvolvimento, promovendo a liberdade e a igualdade perante a lei e na lei, já que toda e qualquer pessoa passaria a ter acesso aos Tribunais na busca de seus direitos.

O desenvolvimento toma-se como referência o conceito substancial de liberdade, da obra de Amartya Sem. Verifica-se que o acesso à justiça é um instrumento para a promoção da capacidade geral dos indivíduos e a criação de novas oportunidades individuais e coletivas. E, é nessa perspectiva das capacidades, "Capability Approach"24, e não de critérios meramente econômicos, que se arquiteta a correlação entre acesso à justiça e desenvolvimento.

O desenvolvimento como liberdade pode ser interpretado como o desenvolvimento como expansão de capacitações, entendida a capacidade como a liberdade substantiva dos indivíduos de fazer escolhas conscientes de estilos de vida25. E o acesso à justiça parece ser o meio mais hábil para essa transformação social, já que é um instrumento à disposição do cidadão

23 PACTO INTERNACIONAL DE DIREITOS CIVIS E POLÍTICOS. 1966. Disponível em: < http://www.planalto.gov.br/ccivil_03/decreto/1990-1994/d0592.htm>. Acesso em: 20 abr. 2017.

${ }^{24}$ SEN, Amartya. Desenvolvimento como liberdade. $1^{\text {a }}$ Ed. São Paulo: Companhia das Letras, 2000. p.86.

25 O benefício da assistência jurídica é, em última análise, ampliar a capacidade do indivíduo para construir seu próprio bem-estar. Faz-se digno citar o pensamento de Amartya Sen, nobel de economia em 1998: "Mesmo que os mais utilizados critérios econômicos do progresso, refletidos em uma massa de estatísticas disponíveis, tendam a se concentrar especificamente no melhoramento de objetos inanimados de conveniência (por exemplo, no produto nacional bruto, PNB, e o produto interno bruto, PIB, que têm sido o foco de uma miríade de estudos econômicos do progresso), essa concentração poderia ser justificada tanto quanto isso fosse possível - em última instância apenas através do que esses objetos produzem nas vidas humanas que eles podem direta ou indiretamente influenciar. Há um reconhecimento crescente favorável à utilização direta de indicadores da qualidade de vida, do bem-estar e das liberdades que as vidas humanas podem trazer consigo. " SEN, Amartya. Desenvolvimento como liberdade. $1^{\text {a }}$ Ed. São Paulo: Companhia das Letras, 2000. p.86. 
BARROS, Renata Furtado; MACHADO, José Alberto Oliveira de Paula. Da autonomia a universalização do acesso à justiça: a narrativa da Defensoria Pública pelas Emendas Constitucionais. Revista Eletrônica Direito e Política, Programa de Pós-Graduação Stricto Sensu em Ciência Jurídica da UNIVALI, Itajaí, v.13, n.1, $1^{\circ}$ quadrimestre de 2018. Disponível em: www.univali.br/direitoepolitica - ISSN 1980-7791

para sua emancipação, exercitando sua própria liberdade na formação do seu estilo de vida pelos direitos, tanto na esfera privada quanto na esfera pública.

Deste modo, não bastaria a mera formalização de um direito em um ordenamento, seria necessário garantir também os meios de os assegurar. Um sistema jurídico e igualitário que pretenda garantir e não apenas formalizar os direitos de todos.

A iniciativa tem papel de destaque na obra de Mauro Cappelletti e Bryant Garth, na década de 70, denominada Acesso à Justiça, adotada como marco doutrinário para a discussão da efetividade desse direito a reclamar direitos ${ }^{26}$. Assentam os autores que não basta simplesmente franquear 0 ingresso do indivíduo nas edificações que sediam a Jurisdição, mas sim conceder-Ihe a consciência de seus direitos, mediante completa orientação jurídica que lhe possibilite até mesmo decidir entre utilizar ou não os instrumentos processuais que a legislação coloca à sua disposição. É a busca por tornar o sistema jurisdicional acessível à população, sobretudo de baixa renda, propiciando a resolução de seus litígios sob os auspícios do Estado e buscando resultados ${ }^{27}$.

O despertar para a efetividade desse acesso à Justiça e a busca por solução de seus problemas práticos fez surgir três enfoques.

No primeiro momento, denominado por Cappelletti e Garth de "primeira onda do acesso à justiça"28, fez-se necessário lutar pela assistência judiciária gratuita. Tal proposição se fundamenta no custo envolvido para a proposição de uma ação judicial (taxas, honorários de perícia, pagamento de advogado), o que representa uma barreia aos necessitados na procura

26 CAPPELLETTI, Mauro; GARTH, Brian. Acesso à Justiça. Tradução de Ellen Gracie Northfleet. Porto Alegre: Sérgio Antônio Fabris, 1988. p.9.

27 CAPPELLETTI, Mauro; GARTH, Brian. Acesso à Justiça. p.10.

28 CAPPELLETTI, Mauro; GARTH, Brian. Acesso à Justiça. p.12. 
BARROS, Renata Furtado; MACHADO, José Alberto Oliveira de Paula. Da autonomia a universalização do acesso à justiça: a narrativa da Defensoria Pública pelas Emendas Constitucionais. Revista Eletrônica Direito e Política, Programa de Pós-Graduação Stricto Sensu em Ciência Jurídica da UNIVALI, Itajaí, v.13, n.1, $1^{\circ}$ quadrimestre de 2018. Disponível em: www.univali.br/direitoepolitica - ISSN 1980-7791

de efetivação de seus direitos, quer por ausência de condições iniciais de arcar com essa demanda, quer pela eventual desproporcionalidade entre 0 benefício auferido e as custas demandadas.

A "segunda onda de acesso à justiça"29, identificada por Cappelletti e Garth foi a da proteção dos interesses metaindividuais, pela tutela dos direitos coletivos e difusos. Nessa linha, procurou-se adotar instrumentos de defesa do meio-ambiente, dos consumidores, do patrimônio cultural, histórico e artístico, moralidade administrativa, entre outros.

Por fim, "a terceira onda de acesso à justiça"30 foi denominada pelos autores de um novo enfoque de acesso à justiça, cuja atenção está centrada no "conjunto geral de instituições e mecanismos, pessoas e procedimentos utilizados para processar e mesmo prevenir disputas nas sociedades modernas." 31

O escopo do artigo é investigar os desafios da Defensoria Pública e de sua normatização na solução da denominada "primeira onda".

\section{ASSISTÊNCIA JURÍDICA: MODELOS}

No que concerne a problemática da chamada "primeira onda", imperioso é revolver o debate entre assistência judiciária e assistência jurídica. Isso porque o serviço de acesso à justiça não se confunde apenas com acessibilidade formal ao Poder Judiciário ou assistência judiciária.

Com mais argúcia esclarece o autor Cichocki Neto:

A expressão "acesso à justiça" engloba um conteúdo de largo espectro: parte da simples compreensão do ingresso do indivíduo em juízo, perpassa por aquela que enforca o processo como instrumento para a

\footnotetext{
${ }^{29}$ CAPPELLETTI, Mauro; GARTH, Brian. Acesso à Justiça. p.18.

30 CAPPELLETTI, Mauro; GARTH, Brian. Acesso à Justiça. p.22.

31 CAPPELLETTI, Mauro; GARTH, Brian. Acesso à Justiça. p.25.
} 
BARROS, Renata Furtado; MACHADO, José Alberto Oliveira de Paula. Da autonomia a universalização do acesso à justiça: a narrativa da Defensoria Pública pelas Emendas Constitucionais. Revista Eletrônica Direito e Política, Programa de Pós-Graduação Stricto Sensu em Ciência Jurídica da UNIVALI, Itajaí, v.13, n.1, $1^{\circ}$ quadrimestre de 2018. Disponível em: www.univali.br/direitoepolitica - ISSN 1980-7791

realização dos direitos individuais, e, por fim, aquela mais ampla, relacionada a uma das funções do próprio Estado a quem compete, não apenas garantir a eficiência do ordenamento jurídico; mas, outrossim, proporcionar a realização da justiça aos cidadãos ${ }^{32}$.

O Poder Judiciário é apenas um dos meios que possibilita o reconhecimento e a efetivação de direitos. O verdadeiro objetivo está na acessibilidade judicial e extrajudicial à uma ordem jurídica justa, alcançável a todos, notadamente, aos mais necessitados, auxiliando assim ao propósito de estabelecimento de uma igualdade formal e material para toda a população.

E, essa acessibilidade para os menos afortunados, somente é possível por intermédio da criação de uma estrutura de assistência jurídica e não meramente judiciária. Diferentes modelos têm sido adotados para esse desiderato, conforme assinala Cleber Francisco Alves que há:

1) os sistemas que funcionam com advogados autônomos, os quais atuam sem receber contraprestação pecuniária dos cofres públicos, a título pro bono, em regime assistencial-caritativo; 2) os sistemas que funcionam com advogados assalariados, que trabalham normalmente em regime de dedicação exclusiva, cuja remuneração provém direta ou indiretamente dos cofres públicos, também denominado de "Salaried Staff Model"; 3) os sistemas que funcionam com advogados autônomos, que atuam como profissionais liberais e que são remunerados na base do caso-acaso pelos cofres públicos, também denominado de "Judicare"; e 4) os sistemas mistos ou híbridos que adotam diversas modalidades de combinações possíveis entre os modelos básicos acima mencionados ${ }^{33}$.

Cada um desses modelos de assistência jurídica a população de baixa renda possui seus pontos positivos e pontos negativos, conforme uma análise de abrangência, de economia, organicidade e de efetiva transformação social.

32 CICHOCKI NETO, José. Limitações ao acesso à justiça. Curitiba: Juruá, 2001.p.46.

33 ALVES, Cleber Francisco. Justiça para Todos! Assistência Jurídica Gratuita nos Estados Unidos, na França e no Brasil. p.67. 
BARROS, Renata Furtado; MACHADO, José Alberto Oliveira de Paula. Da autonomia a universalização do acesso à justiça: a narrativa da Defensoria Pública pelas Emendas Constitucionais. Revista Eletrônica Direito e Política, Programa de Pós-Graduação Stricto Sensu em Ciência Jurídica da UNIVALI, Itajaí, v.13, n.1, 10 quadrimestre de 2018. Disponível em: www.univali.br/direitoepolitica - ISSN 1980-7791

O primeiro modelo possui como entrave a quantidade de demanda existente para uma pequena parcela de voluntários e a dificuldade de fazer arranjos sistematizados e planejados para melhor garantir acesso à ordem jurídica justa para a população carente. É um modelo para situações pontuais que precisa ainda contar com a disponibilidade de altruísmo alheio, sendo, portanto, inviável para repensar o acesso à justiça como um projeto de transformação social e direito de emancipação ${ }^{34}$.

O segundo modelo, "salaried staff", tem como ponto positivo a possibilidade de fazer do acesso à justiça uma política pública sistematizada e abrangente de conscientização de direitos e de emancipação do cidadão de baixa renda. Logo, sua estrutura permite alcançar mais resultados para uma efetiva transformação social do indivíduo e da coletividade. Possui a desvantagem de ser mais um custo para o welfare state. E, ainda, pode haver uma incongruência entre o fato de o órgão instituído para esse desiderato ser financiado pelo governo ao mesmo tempo em que combate várias das políticas estatais.

Assim também manifesta Cappelletti e Garth:

As vantagens dessa sistemática (o staff model) sobre o judicare são óbvias. Ela ataca outras barreiras ao acesso individual, além dos custos, particularmente os problemas derivados da desinformação jurídica pessoal dos pobres. Ademais, ela pode apoiar os interesses difusos ou de classes das pessoas pobres. Esses escritórios, que reúnem advogados numa equipe, podem assegurar-se as vantagens dos litigantes organizacionais, adquirindo conhecimento e experiência dos problemas típicos dos pobres. Advogados particulares, encarregados apenas de atender a indivíduos, geralmente não são capazes de assegurar essas vantagens. Em suma [...] esse modelo: 1) vai em direção aos pobres para auxiliá-los a reivindicar seus

34 ALVES, Cleber Francisco. Justiça para Todos! Assistência Jurídica Gratuita nos Estados Unidos, na França e no Brasil. p.91. 
BARROS, Renata Furtado; MACHADO, José Alberto Oliveira de Paula. Da autonomia a universalização do acesso à justiça: a narrativa da Defensoria Pública pelas Emendas Constitucionais. Revista Eletrônica Direito e Política, Programa de Pós-Graduação Stricto Sensu em Ciência Jurídica da UNIVALI, Itajaí, v.13, n.1, 10 quadrimestre de 2018. Disponível em: www.univali.br/direitoepolitica - ISSN 1980-7791

direitos e 2) cria uma categoria de advogados eficientes para atuar pelos pobres, enquanto classe ${ }^{35}$.

A ideia do terceiro modelo chamado de "sistema judicare" é proporcionar aos litigantes de baixa renda a mesma representação que teriam se pudessem pagar um advogado. Porém esse método é que ele se volta para a defesa eminentemente individual do assistido, desconsiderando a importância do enfoque nos direitos coletivos. Além disso, não há a preocupação com a formação de uma consciência dos direitos cabíveis às pessoas. As pessoas que, em regra, mais possuem seus direitos violados, passam a ser também as mais prejudicadas por sequer saber identificá-los.

Boaventura de Souza Santos faz o seguinte contraponto sobre o sistema "judicare":

Este sistema limita-se a tentar vencer os obstáculos econômicos ao acesso à justiça, mas não os obstáculos sociais e culturais. Nada faz no domínio da educação jurídica dos cidadãos, da conscientização sobre os novos direitos sociais dos trabalhadores, consumidores, inquilinos, jovens, mulheres, etc. Por último, concebendo a assistência judiciária como um serviço prestado a cidadãos de menos recursos individualmente considerados, este sistema excluía, à partida, a concepção dos problemas desses cidadãos enquanto problemas colectivos das classes sociais subordinadas ${ }^{36}$.

E como se pode depreender a Constituição Federal de 1988 adotou o "salaried staff model", isto é, a necessidade de o Estado se incumbir de prestar assistência jurídica (judicial e extrajudicial), aos que comprovarem insuficiência de recursos ${ }^{37}$, elencando-a como direito fundamental e criando a Defensoria Pública, como instituição essencial à Justiça.

35 CAPPELLETTI, Mauro; GARTH, Brian. Acesso à Justiça. p.40.

36 SANTOS, Boaventura de Sousa. Pela mão de Alice - o social e o político na pósmodernidade. 5a ed. São Paulo: Cortez, 1999, p. 171.

37 Mesmo entre as Defensorias Públicas Estaduais e Federal não há uma uniformidade na conceituação de "necessitados", ora assim sendo definidos os que se enquadram nos 
BARROS, Renata Furtado; MACHADO, José Alberto Oliveira de Paula. Da autonomia a universalização do acesso à justiça: a narrativa da Defensoria Pública pelas Emendas Constitucionais. Revista Eletrônica Direito e Política, Programa de Pós-Graduação Stricto Sensu em Ciência Jurídica da UNIVALI, Itajaí, v.13, n.1, $1^{\circ}$ quadrimestre de 2018. Disponível em: www.univali.br/direitoepolitica - ISSN 1980-7791

\section{DEFENSORIA PÚBLICA E SUAS REFORMAS CONSTITUCIONAIS}

Nessa sessão serão abordadas as mudanças constitucionais do perfil da Defensoria Pública pelo Poder Constituinte Derivado Reformador. Iniciaremos a análise com o texto originário, passando pelas inovações realizadas pela Emenda Constitucional n045/2004 e finalizando com os novos desafios lançados pela Emenda Constitucional no 80/2014.

O exame de cada fase será realizado em cotejo com dados que refletem as repercussões práticas de cada reforma constitucional. Para esse intento, foram utilizadas as pesquisas quantitativas publicadas pelo Ministério da Justiça nesse período, através I, II, III, e IV Diagnóstico da Defensoria Pública no Brasil publicado pelo Ministério da Justiça no ano de 2004, 2006, 2009 e 2015, respectivamente.

\subsection{O PROJETO DO CONSTITUINTE ORIGINÁRIO}

A redação original do artigo $134^{\circ}$ da promulgada Constituição Federal em 1988 assim planejava a Defensoria Pública:

Artigo 134. A Defensoria Pública é instituição essencial à função jurisdicional do Estado, incumbindo-lhe a orientação jurídica e a defesa, em todos os graus, dos necessitados, na forma do artigo 50, LXXIV.

Parágrafo único. Lei complementar organizará a Defensoria Pública da União e do Distrito Federal e dos Territórios e prescreverá normas gerais para sua organização nos Estados, em cargos de carreira, providos, na classe inicial, mediante concurso público de provas e títulos, assegurada a seus integrantes a garantia da inamovibilidade e vedado o exercício da advocacia fora das atribuições institucionais ${ }^{38}$.

critérios de isenção de imposto de renda, ora os que recebem até dois ou três salários mínimos nacionais.

38 BRASIL. Constituição (1988). Constituição da República Federativa do Brasil. Brasília, DF: Senado, 1988. 
BARROS, Renata Furtado; MACHADO, José Alberto Oliveira de Paula. Da autonomia a universalização do acesso à justiça: a narrativa da Defensoria Pública pelas Emendas Constitucionais. Revista Eletrônica Direito e Política, Programa de Pós-Graduação Stricto Sensu em Ciência Jurídica da UNIVALI, Itajaí, v.13, n.1, 10 quadrimestre de 2018. Disponível em: www.univali.br/direitoepolitica - ISSN 1980-7791

Apesar da normatização prévia nas legislaturas estaduais do Rio de Janeiro e Minas Gerais ${ }^{39}$, a maior parte das Defensorias Públicas foram criadas após a Constituição de 1988.

Passados dezesseis anos dessa novidade constitucional, em 2004, 0 Ministério da Justiça publicou o I Diagnóstico da Defensoria Pública no Brasil com o objetivo de realizar um estudo nacional para servir de apoio ao planejamento das transformações do sistema Justiça.

Das informações colhidas pelo diagnóstico, foram observadas situações críticas. Passados mais de uma década do novo regime democrático, Goiás, Santa Catarina, São Paulo, Paraná e Rio Grande do Norte, ainda não dispunham dos serviços prestados pela Defensoria Pública aos cidadãos necessitados ${ }^{40}$.

Dos Estados em que havia Defensoria Pública, em média, eram atendidas apenas $53 \%$ das comarcas. $^{41} \mathrm{E}$ ainda constatou-se que maior era a ausência de Defensorias Públicas precisamente nos locais onde sua atuação seria mais necessária, isto é, nos Estados com os piores indicadores no que diz respeito à escolaridade, à renda per capita e à longevidade. Em outras palavras, quanto pior o IDH, menor o volume de recursos destinados para o atendimento do cidadão.

Concluiu o diagnóstico: "a soma e a combinação dessa série de dados apontam a presença de um círculo vicioso: quanto maior o número de

39 Embora só tenha se estruturado na forma da Lei Orgânica Nacional (LC n. 80, de 1994) em 2003. MORAES, Humberto Peña de; DA SILVA, José Fontenelle Teixeira. Assistência Judiciária: Sua Gênese, Sua História e a Função Protetiva do Estado. p.91.

40 BRASIL Ministério da Justiça- I Diagnóstico da Defensoria Pública no Brasil. Brasília. 2004. Disponível em: <https://www.anadep.org.br/wtksite/downloads/ Diag_defensoria.pdf> Acesso em 18/06/2017.

41 BRASIL Ministério da Justiça- I Diagnóstico da Defensoria Pública no Brasil. Brasília. 2004. Disponível em: <https://www.anadep.org.br/wtksite/downloads/ Diag_defensoria.pdf> Acesso em 18/06/2017. 
BARROS, Renata Furtado; MACHADO, José Alberto Oliveira de Paula. Da autonomia a universalização do acesso à justiça: a narrativa da Defensoria Pública pelas Emendas Constitucionais. Revista Eletrônica Direito e Política, Programa de Pós-Graduação Stricto Sensu em Ciência Jurídica da UNIVALI, Itajaí, v.13, n.1, $1^{\circ}$ quadrimestre de 2018. Disponível em: www.univali.br/direitoepolitica - ISSN 1980-7791

cidadãos carentes, menos Defensorias, menores recursos, menor procura pelos serviços e maiores custos ${ }^{42 "}$.

A despeito das diferenças entre as Defensorias, todas elas sofreram, em maior ou menor medida, as consequências da ausência de autonomia e da subordinação ao Executivo. Esse status constrangia a possibilidade de executar projetos próprios, condizentes com as prioridades estabelecidas pela própria instituição. Não controlando os recursos para o exercício de gerenciamento interno, eram limitadas as condições para o exercício de autogestão e de definição e implementação de políticas adequadas e de qualidade.

Dos dados são notáveis as variações de arranjo organizacional e operacional entre as unidades da Federação. E o I Diagnóstico pôs em evidência a precariedade do acesso à Justiça até então no país. Por este motivo, o governo federal estabeleceu como ponto prioritário na reforma constitucional do Judiciário a concessão de autonomia funcional, administrativa e iniciativa de proposta orçamentária à Defensoria, meio de se reverter o processo de apatia e indiferença com assistência jurídica gratuita que marcou a década de 90 .

\subsection{EMENDA No 45/2004: AUTONOMIA DAS DEFENSORIAS PÚBLICAS ESTADUAIS}

Após dez anos de tramitação, a PEC da Reforma do Judiciário foi finalmente aprovada no Senado e promulgada em 2004, conferindo a prometida autonomia às Defensorias Públicas Estaduais, a partir da concepção de que não bastava o enfrentamento dos problemas crônicos do Judiciário, sendo necessário também ampliar e aprimorar o acesso à Justiça. E o fortalecimento da Defensoria Pública foi adotado, acertadamente, como diretriz desse projeto.

42 BRASIL Ministério da Justiça- I Diagnóstico da Defensoria Pública no Brasil. Brasília. 2004. Disponível em: <https://www.anadep.org.br/wtksite/downloads/ Diag_defensoria.pdf> Acesso em 18/06/2017. 
BARROS, Renata Furtado; MACHADO, José Alberto Oliveira de Paula. Da autonomia a universalização do acesso à justiça: a narrativa da Defensoria Pública pelas Emendas Constitucionais. Revista Eletrônica Direito e Política, Programa de Pós-Graduação Stricto Sensu em Ciência Jurídica da UNIVALI, Itajaí, v.13, n.1, $1^{\circ}$ quadrimestre de 2018. Disponível em: www.univali.br/direitoepolitica - ISSN 1980-7791

Com a Emenda no 45/2004, a redação do artigo $134^{\circ}$ da Constituição Federal não sofreu modificação, porém acrescentou-se um parágrafo segundo, que assegura autonomia funcional, administrativa e a iniciativa de sua proposta orçamentária para a Defensoria Pública.

Como objetivo de atualizar e avaliar as modificações no perfil da instituição no interregno de dois anos foi realizado em 2006, o II Diagnóstico da Defensoria Pública no Brasil.

A novidade desta nova pesquisa foi a inclusão das Defensorias Públicas do Rio Grande do Norte e de São Paulo, criadas, respectivamente, em 2005 e 2006. O Estado de Goiás também aprovou a lei que criou a Defensoria Pública, mas não a instalou ${ }^{43}$.

O II Diagnóstico apontou vários avanços alcançados. No marco legislativo, sem dúvida, a principal alteração foi a sobredita conquista da autonomia funcional, administrativa e orçamentária, consagrada pela Emenda Constitucional no. 45/2004. Essa inovação foi seguida por alterações nas legislações de diversos Estados, buscando adequar-se a essa nova realidade. O quadro geral, porém, ainda apontava várias dificuldades, notadamente em termos de concretização da autonomia, estrutura, recursos e número de defensores.

Um dos indicadores do grau de efetividade da autonomia da Defensoria Pública é a observância, por parte do ente federativo, à obrigatoriedade de repassar as cotas mensais do orçamento destinado à instituição (duodécimos), conforme previsto no artigo 168 da Constituição da República. Porém, apenas o Estado de Roraima cumpria integralmente o mandamento constitucional. Nos Estados do Acre, Amazonas, Ceará, Mato Grosso do Sul, Pará, Paraíba, Rondônia, Rio de Janeiro e Tocantins, o

43 BRASIL Ministério da Justiça- II Diagnóstico da Defensoria Pública no Brasil. Brasília. 2006. Disponível em: <https://www.anadep.org.br/wtksite/downloads/ Diag_defensoria_II.pdf> Acesso em 18/06/2017. 
BARROS, Renata Furtado; MACHADO, José Alberto Oliveira de Paula. Da autonomia a universalização do acesso à justiça: a narrativa da Defensoria Pública pelas Emendas Constitucionais. Revista Eletrônica Direito e Política, Programa de Pós-Graduação Stricto Sensu em Ciência Jurídica da UNIVALI, Itajaí, v.13, n.1, $1^{\circ}$ quadrimestre de 2018. Disponível em: www.univali.br/direitoepolitica - ISSN 1980-7791

repasse era feito ainda parcialmente ${ }^{44}$. Nos demais Estados sequer reconhecia ainda a autonomia da Defensoria Pública.

De toda forma, como reflexo dessa emenda, em seis Estados os Defensores Públicos Gerais passaram a gozar da iniciativa legislativa para criação de cargos, ao passo que em 2003 apenas duas Defensorias detinham essa atribuição. Dessa forma, "o número de cargos existentes de defensor público aumentou em 23,8\%, passando para o total de 6.575 cargos" $^{45}$. "E - número absoluto de comarcas atendidas pela Defensoria Pública aumentou em 19,9\%. Porém, o número de comarcas existentes no país foi ampliado em $27,2 \% " 46$. Portanto, o crescimento da cobertura do serviço pela Defensoria não foi suficiente para acompanhar o crescimento da cobertura do Poder Judiciário.

No mês de outubro de 2009 foi promulgada a Lei Complementar Federal no. 132, o que consistiu em mais um ponto de inflexão para a ampliação das funções institucionais, modernização e democratização da gestão da Defensoria Pública.

No bojo da lei foi introduzido mecanismos de participação social na gestão e direitos dos usuários do serviço de prestação da assistência jurídica gratuita. Inovou também ao expressar de forma inequívoca a necessidade prioritária de atuação extrajudicial, com adoção de políticas de prevenção e de solução alternativa de conflito, e coletiva, de forma a garantir racionalidade na judicialização das novas demandas.

44 BRASIL Ministério da Justiça- II Diagnóstico da Defensoria Pública no Brasil. Brasília. 2006. Disponível em: <https://www.anadep.org.br/wtksite/downloads/ Diag_defensoria_II.pdf> Acesso em 18/06/2017.

45 BRASIL Ministério da Justiça- II Diagnóstico da Defensoria Pública no Brasil. Brasília. 2006. Disponível em: <https://www.anadep.org.br/wtksite/downloads/ Diag_defensoria_II.pdf> Acesso em 18/06/2017.

46 BRASIL Ministério da Justiça- II Diagnóstico da Defensoria Pública no Brasil. Brasília. 2006. Disponível em: <https://www.anadep.org.br/wtksite/downloads/ Diag_defensoria_II.pdf> Acesso em 18/06/2017. 
BARROS, Renata Furtado; MACHADO, José Alberto Oliveira de Paula. Da autonomia a universalização do acesso à justiça: a narrativa da Defensoria Pública pelas Emendas Constitucionais. Revista Eletrônica Direito e Política, Programa de Pós-Graduação Stricto Sensu em Ciência Jurídica da UNIVALI, Itajaí, v.13, n.1, 10 quadrimestre de 2018. Disponível em: www.univali.br/direitoepolitica - ISSN 1980-7791

Nesse novo cenário, foi publicado o III Diagnóstico sobre a Defensoria Pública no Brasil, no qual depreendeu que Paraná, Amapá, e Goiás ainda não haviam estruturado o serviço público na forma da Carta Constitucional e o Estado de Santa Catarina permanecia inerte, sem, até aquele momento, oferecer algum tipo de serviço público nesse sentido ${ }^{47}$.

Mas decorrido cinco anos da Emenda na45/2004, a autonomia com relação ao Poder Executivo já passou a ser observada em $92 \%$ das instituições. ${ }^{48}$ Somente duas Defensorias Públicas dos Estados continuaram subordinadas a alguma secretaria do Executivo, sendo que a Defensoria Pública da União somente com a Emenda no. 74/2013, que incluiu o $\S 3^{\circ}$ no artigo $134^{\circ}$ da Constituição Federal, angariou esse status.

Nessa edição do diagnóstico, observou-se apenas um pequeno incremento no percentual de comarcas atendidas ${ }^{49}$, entretanto tão-somente no período de 2006 a 2008, notou-se o aumento substantivo no volume de trabalho dos defensores públicos: "o número de atendimentos realizados aumentou em $45,17 \%$ e o número de ações ajuizadas ou respondidas majorou em $66,59 \% " 50$.

O III Diagnóstico da Defensoria Pública tornou-se instrumento fundamental para avaliar os avanços da instituição, mapear os entraves e refletir sobre a amplitude vocacional da Defensoria Pública na assistência jurídica integral. As respostas mostraram, acima de tudo, o quanto ainda era inibida a

47 BRASIL Ministério da Justiça- III Diagnóstico da Defensoria Pública no Brasil. Brasília. 2009. Disponível em: <https://www.anadep.org.br/wtksite/IIIdiag_ DefensoriaP.pdf> Acesso em 18/06/2017.

48 BRASIL Ministério da Justiça- III Diagnóstico da Defensoria Pública no Brasil. Brasília. 2009. Disponível em: <https://www.anadep.org.br/wtksite/IIIdiag_ DefensoriaP.pdf > Acesso em 18/06/2017.

${ }^{49}$ Algumas Defensorias não responderam esta pergunta, o que prejudicou o levantamento das informações

50 BRASIL Ministério da Justiça- III Diagnóstico da Defensoria Pública no Brasil. Brasília. 2009. Disponível em: <https://www.anadep.org.br/wtksite/IIIdiag_ DefensoriaP.pdf> Acesso em 18/06/2017. 
BARROS, Renata Furtado; MACHADO, José Alberto Oliveira de Paula. Da autonomia a universalização do acesso à justiça: a narrativa da Defensoria Pública pelas Emendas Constitucionais. Revista Eletrônica Direito e Política, Programa de Pós-Graduação Stricto Sensu em Ciência Jurídica da UNIVALI, Itajaí, v.13, n.1, $1^{\circ}$ quadrimestre de 2018. Disponível em: www.univali.br/direitoepolitica - ISSN 1980-7791

atuação defensorial no sentido de desenvolver um trabalho sistemático de informação sobre direitos, sobre cidadania e na promoção dos direitos humanos. É sob essas novas conjecturas que insurgiu o telos da aprovação de uma nova Emenda Constitucional no ano de 2014.

\subsection{NOVOS E VELHOS DESAFIOS COM A EMENDA No 80/2014}

Tão paradigmática quanto a emenda $\mathrm{n}^{\circ} .45$ de 2004, a recente emenda constitucional no 80 de 2014, alçou um novo perfil constitucional para a Defensoria Pública, com uma inédita redação no caput do artigo 1340, originando as seguintes inovações: 1) garantir a existência de defensores públicos em todas as unidades jurisdicionais no prazo máximo de oito anos; 2) inserção da Defensoria Pública em seção exclusiva no rol das funções essenciais à Justiça, separada, agora, da advocacia; 3) tornou-se instituição permanente; 4) explicitação ampla do conceito e da missão da Defensoria Pública; 5) inclusão dos princípios institucionais da Defensoria Pública no texto constitucional; e 6) aplicação de parte do regramento jurídico do Poder Judiciário, no que couber, à Defensoria Pública, principalmente a iniciativa de lei.

Dentre essas inovações constitucionais, duas se destacam. A primeira é a iniciativa legislativa conferida a Defensoria Pública, requisito fundamental para concretizar a autonomia. A segunda é a norma programática na qual o Poder Público tem até 2022 para universalizar o acesso à Justiça e ter defensores públicos em todas as comarcas do país.

Mais precisamente o artigo $98^{\circ}$ no Ato das Disposições Transitórias passou a prescrever que no prazo de 8 (oito) anos, a União, os Estados e o Distrito Federal deverão contar com defensores públicos em todas as unidades jurisdicionais, devendo a lotação seguir as regiões com maiores índices de exclusão social e adensamento populacional ${ }^{51}$.

51 BRASIL. Constituição (1988). Constituição da República Federativa do Brasil. Brasília, DF: Senado, 1988. 
BARROS, Renata Furtado; MACHADO, José Alberto Oliveira de Paula. Da autonomia a universalização do acesso à justiça: a narrativa da Defensoria Pública pelas Emendas Constitucionais. Revista Eletrônica Direito e Política, Programa de Pós-Graduação Stricto Sensu em Ciência Jurídica da UNIVALI, Itajaí, v.13, n.1, 10 quadrimestre de 2018. Disponível em: www.univali.br/direitoepolitica - ISSN 1980-7791

Ocorre que em relação a esse cumprimento, o IV Diagnóstico da Defensoria Pública no Brasil, realizado pelo Ministério da Justiça em 2014, indica que com exceção de unidades federativas como o Rio de Janeiro, Rio Grande do Sul, Tocantins, Roraima e Rondônia, com aproximadamente $100 \%$ de atendimento nas comarcas, as demais unidades ainda precisam avançar sistematicamente para conseguir cumprir a tempo o mandamento dessa Emenda Constitucional ${ }^{52}$.

Os cenários mais desafiadores em termos da proporção de comarcas ainda sem atendimento estão localizados nos estados de Goiás $(97,7 \%)$, Bahia $(89,9 \%)$, Rio Grande do Norte $(86,2 \%)$, Paraná $(85,4 \%)$ e São Paulo $(84,2 \%)^{53}$. Válido é assentar que somente em 2011 e 2012 os Estados do Paraná e de Santa Catarina, respectivamente, criaram as Defensorias Públicas que faltavam no país.

Os recursos humanos dos quais dispõem as Defensorias Públicas brasileiras, embora venham sendo significativamente expandido ao longo dos últimos anos, ainda é inferior daquilo que seria adequado para o pleno atendimento à demanda por assistência jurídica no país. E ainda com o resultado da ampliação das Defensorias e de sua responsabilidade social, cresceu o número de atendimentos e de atuações judiciais e extrajudiciais.

De acordo com o diagnóstico, "o ideal é um profissional para atender cada grupo de quinze mil pessoas". ${ }^{4}$ No entanto, o déficit da categoria é de pelo menos seis mil. A balança da Justiça mostra-se ainda mais desequilibrada

52 BRASIL Ministério da Justiça- IV Diagnóstico da Defensoria Pública no Brasil. Brasília. 2015. Disponível em: <https:// www.anadep.org.br/wtksite/downloads/ivdiagnóstico-da-defensoria-publica-no-brasil.pdf> Acesso em 18/06/2017.

53 BRASIL Ministério da Justiça- IV Diagnóstico da Defensoria Pública no Brasil. Brasília. 2015. Disponível em: <https:// www.anadep.org.br/wtksite/downloads/ivdiagnóstico-da-defensoria-publica-no-brasil.pdf> Acesso em 18/06/2017.

54 BRASIL Ministério da Justiça- IV Diagnóstico da Defensoria Pública no Brasil. Brasília. 2015. Disponível em: <https:// www.anadep.org.br/wtksite/downloads/ivdiagnóstico-da-defensoria-publica-no-brasil.pdf> Acesso em 18/06/2017. 
BARROS, Renata Furtado; MACHADO, José Alberto Oliveira de Paula. Da autonomia a universalização do acesso à justiça: a narrativa da Defensoria Pública pelas Emendas Constitucionais. Revista Eletrônica Direito e Política, Programa de Pós-Graduação Stricto Sensu em Ciência Jurídica da UNIVALI, Itajaí, v.13, n.1, 10 quadrimestre de 2018. Disponível em: www.univali.br/direitoepolitica - ISSN 1980-7791

quando comparado ao número de juízes (11.807) e de promotores $(10.874)^{55}$.

E não se pode olvidar que a atuação da Defensoria Pública não se restringe a preencher lacunas de comarcas e unidades jurisdicionais "varas". A missão constitucional dada à Defensoria Pública de assistência jurídica integral é mais extensa porque abrange também a atividade extrajudicial, a saber, prestar orientação jurídica, promovendo, prioritariamente, a solução extrajudicial dos litígios e a educação em direitos como forma de prevenção ${ }^{56}$. Esse amplo espectro de formas de acesso à justiça exige, inclusive, o planejamento de um quadro de pessoal que preveja mais do que um defensor público por órgão jurisdicional.

Em suma a Emenda Constitucional no 80/2014 prevê a capilarização das Defensorias Públicas em oito anos. Mas a projeção desse cumprimento desvela um cenário complexo para a maioria dos Estados brasileiros, em consonância com as evidências levantadas:

São Paulo, por exemplo, é o estado que tem os maiores desafios à frente, pois, para que cumpra completamente as metas estabelecidas pela EC, precisa expandir a Defensoria Pública Estadual a 195 unidades jurisdicionais por ano. Minas Gerais precisa levar a DPE a quase 94 unidades jurisdicionais por ano até 2022, e a Bahia precisa garantir, anualmente, a expansão da DPE a 88 jurisdições ${ }^{57}$.

55 BRASIL Ministério da Justiça- IV Diagnóstico da Defensoria Pública no Brasil. Brasília. 2015. Disponível em: <https:// www.anadep.org.br/wtksite/downloads/ivdiagnóstico-da-defensoria-publica-no-brasil.pdf> Acesso em 18/06/2017.

56 LIMA, Frederico Rodrigues Viana. Defensoria Pública. Salvador: JusPODIVM, 2014. p.64.

57 BRASIL Ministério da Justiça- IV Diagnóstico da Defensoria Pública no Brasil. Brasília. 2015. Disponível em: <https:// www.anadep.org.br/wtksite/downloads/ivdiagnóstico-da-defensoria-publica-no-brasil.pdf> Acesso em 18/06/2017. 
BARROS, Renata Furtado; MACHADO, José Alberto Oliveira de Paula. Da autonomia a universalização do acesso à justiça: a narrativa da Defensoria Pública pelas Emendas Constitucionais. Revista Eletrônica Direito e Política, Programa de Pós-Graduação Stricto Sensu em Ciência Jurídica da UNIVALI, Itajaí, v.13, n.1, $1^{\circ}$ quadrimestre de 2018. Disponível em: www.univali.br/direitoepolitica - ISSN 1980-7791

E a percepção apresentada pelos defensores públicos corrobora essa análise, em que cerca de $85 \%$ dos membros creem no inadimplemento dessa meta constitucional ${ }^{58}$.

\section{CONSIDERAÇÕES FINAIS}

O direito do acesso à justiça não é apenas uma garantia constitucional, é uma prerrogativa associada aos Direitos Humanos, dotada de grande importância quando se considera o desafio de transformação das estruturas sociais e políticas construídas na modernidade.

A locução acesso à justiça tem uma difícil definição em razão da ampla abrangência de seu significado, pois compreende todos os meios a que se destina a um fim, a saber: a reivindicação dos direitos dos cidadãos, orientação jurídica, educação de direitos e a solução dos litígios dos indivíduos, por meio de um sistema que deve proporcionar não só o acesso a todos aos resultados e soluções justas, mas também a ampliação das capacitações e oportunidades para os cidadãos.

Um dos desafios do acesso à justiça pode ser resumido na denominada primeira onda, expressão cunhada por Mauro Cappelletti e Briant Garth para fazer referência à necessidade de criação de estruturas de assistência jurídica para a população desfavorecida, sob pena de violação ao princípio da igualdade e do direito ao desenvolvimento.

E mais do que a distinção terminológica, o imperioso é que a assistência jurídica se torne efetiva e desempenhe a nobre função de humanizar o acesso à ordem jurídica, deixando o diminuto papel de mera assistência judiciária. Não se trata, aqui, da garantia meramente formal do direito de ação, mas sim, do acesso efetivo e pleno à ordem jurídica justa, da

58 BRASIL Ministério da Justiça- IV Diagnóstico da Defensoria Pública no Brasil. Brasília. 2015. Disponível em: <https:// www.anadep.org.br/wtksite/downloads/ivdiagnóstico-da-defensoria-publica-no-brasil.pdf> Acesso em 18/06/2017. 
BARROS, Renata Furtado; MACHADO, José Alberto Oliveira de Paula. Da autonomia a universalização do acesso à justiça: a narrativa da Defensoria Pública pelas Emendas Constitucionais. Revista Eletrônica Direito e Política, Programa de Pós-Graduação Stricto Sensu em Ciência Jurídica da UNIVALI, Itajaí, v.13, n.1, $1^{\circ}$ quadrimestre de 2018. Disponível em: www.univali.br/direitoepolitica - ISSN 1980-7791

possibilidade de o ser humano conviver em uma sociedade onde o direito é instrumento de exercício e acréscimo da liberdade substantiva.

E a decisão do Constituinte de 1988 foi institucionalizar a Defensoria Pública, órgão estatal funcionalmente especializado nesse mister de assistência jurídica integral, organizado em carreira por ingresso mediante concurso público, revestido de autonomia e prerrogativas, cujo o membro é denominado Defensor Público.

Passadas quase três décadas diversas foram as inovações legislativas que modelaram esse "salaried staff model". Foram destacadas as reformas constitucionais por via das Emendas Constitucionais no 45/2004, 74/2013 e 80/2014 que fortaleceram a instituição conferindo, sobretudo, autonomia e identidade, condições indispensáveis para a efetivação da igualdade jurídica e acesso à justiça.

Quanto ao prazo de garantir a existência de defensores públicos em todas as unidades jurisdicionais no prazo máximo de oito anos a contar da Emenda Constitucional no $80 / 2014$, verificou-se que a projeção de cumprimento desse projeto constitucional ressalta um cenário desafiador para a maioria dos Estados brasileiros, conforme as evidências apontadas.

Isso porque a proporção ainda está muito aquém do nível desejável. Os dados apontam para um desequilíbrio entre as federações na cobertura dos serviços de assistência jurídica prestados pela Defensoria Pública, comprometendo seu potencial de ampliação e universalização do acesso à Justiça pelos brasileiros.

Mesmo constatando o considerável avanço dessa instituição, ainda mais longo será o caminho para a estruturação necessária para o cumprimento da missão constitucional de desenvolver um trabalho sistemático de solução extrajudicial de conflitos, educação em direitos e promoção de direitos humanos e cidadania. 
BARROS, Renata Furtado; MACHADO, José Alberto Oliveira de Paula. Da autonomia a universalização do acesso à justiça: a narrativa da Defensoria Pública pelas Emendas Constitucionais. Revista Eletrônica Direito e Política, Programa de Pós-Graduação Stricto Sensu em Ciência Jurídica da UNIVALI, Itajaí, v.13, n.1, $1^{\circ}$ quadrimestre de 2018. Disponível em: www.univali.br/direitoepolitica - ISSN 1980-7791

\section{REFERÊNCIAS DAS FONTES CITADAS}

ALVES, Cleber Francisco. Justiça para Todos! Assistência Jurídica Gratuita nos Estados Unidos, na França e no Brasil. Rio de Janeiro: Lumen Juris, 2006.

ARENDT, Hannah. Origens do Totalitarismo - Antissemitismo, Imperialismo, Totalitarismo. Tradução de Roberto Raposo. São Paulo: Companhia das Letras, 1989.

BASTOS, Celso Ribeiro Bastos. Comentários à Constituição do Brasil. 20 volume. $1^{\text {a }}$ ed. São Paulo: Saraiva, 1989.

BORGE, Felipe Dezorzi. Defensoria Pública: uma breve história. Revista Jus Navigandi, ISSN 1518-4862, Teresina, ano 15, n. 2480, 16abr. 2010. Disponível em: <https://jus.com.br/artigos/14699>. Acesso em: 19 jun. 2017.

BRASIL. Constituição (1988). Constituição da República Federativa do Brasil. Brasília, DF: Senado, 1988.

BRASIL. Constituição (1934). Constituição da República dos Estados Unidos do Brasil (1934). Brasília: Casa Civil, s.d. Disponível em: <https://www2.senado.leg.br/bdsf/bitstream/handle/id/137569/Constituico es_Brasileiras>. Acesso em: 27/04/2017.

BRASIL. Constituição (1946). Constituição dos Estados Unidos do Brasil (1946). Brasília: Casa Civil, s.d Disponível em: <http://www2.camara.leg.br/acamara/conheca/museu/publicacoes/arquivospdf/Constituicoes\%20Brasileiras-PDF.pdf>. Acesso em: 27/04/2017.

BRASIL Ministério da Justiça- I Diagnóstico da Defensoria Pública no Brasil. Brasília. 2004. Disponível em: <https://www.anadep.org.br/wtksite/downloads/ Diag_defensoria.pdf> Acesso em 18/06/2017.

BRASIL Ministério da Justiça- II Diagnóstico da Defensoria Pública no Brasil. Brasília. 2006. Disponível em: <https://www.anadep.org.br/wtksite/downloads/ Diag_defensoria_II.pdf> Acesso em 18/06/2017.

BRASIL Ministério da Justiça- III Diagnóstico da Defensoria Pública no Brasil. $\quad$ Brasília. 2009. Disponível em: <https://www.anadep.org.br/wtksite/IIIdiag_DefensoriaP.pdf> Acesso em $18 / 06 / 2017$.

BRASIL Ministério da Justiça- IV Diagnóstico da Defensoria Pública no Brasil. $\quad$ Brasília. $2015 . \quad$ Disponível em: <https:// 
BARROS, Renata Furtado; MACHADO, José Alberto Oliveira de Paula. Da autonomia a universalização do acesso à justiça: a narrativa da Defensoria Pública pelas Emendas Constitucionais. Revista Eletrônica Direito e Política, Programa de Pós-Graduação Stricto Sensu em Ciência Jurídica da UNIVALI, Itajaí, v.13, n.1, $1^{\circ}$ quadrimestre de 2018. Disponível em: www.univali.br/direitoepolitica - ISSN 1980-7791

www.anadep.org.br/wtksite/downloads/iv-diagnóstico-da-defensoriapublica-no-brasil.pdf> Acesso em 18/06/2017.

CAPPELLETTI, Mauro; GARTH, Brian. Acesso à Justiça. Tradução de Ellen Gracie Northfleet. Porto Alegre: Sérgio Antônio Fabris, 1988.

CICHOCKI NETO, José. Limitações ao acesso à justiça. Curitiba: Juruá, 2001.

COGOY, Daniel Mourgues. Assistência jurídica e judiciária no Brasil: legitimação, eficácia e desafios do modelo brasileiro. Revista da Defensoria Pública da União, n. 5, p. 140-164, out. 2012. Disponível em: $<\quad$ http://revistadadpu.dpu.def.br/index.php/dpu/article/view/70/70 >. Acesso em: 29/06/2017.

DECLARAÇÃO AMERICANA DOS DIREITOS E DEVERES DOS HOMENS. 1948. Disponível em: <https://www.cidh.oas.org/basicos/portugues/b. Declaracao_Americana.htm>. Acesso em: 20/04/2017.

DECLARAÇÃO UNIVERSAL DOS DIREITOS DOS HOMENS. ONU. 1948. Disponível em: <http://www.ohchr.org/EN/UDHR/Documents/UDHR Translations/por.pdf>. Acesso em: 20/04/2017.

GROTTI, Dinorá. O serviço Público e a Constituição Brasileira de 1988. São Paulo: Malheiros Editores, 2003.

LIMA, Frederico Rodrigues Viana. Defensoria Pública. Salvador: JusPODIVM, 2014.

MORAES, Humberto Peña de; DA SILVA, José Fontenelle Teixeira. Assistência Judiciária: Sua Gênese, Sua História e a Função Protetiva do Estado. Rio de Janeiro: Liber Juris, 1984.

MOREIRA NETO, Diogo de Figueiredo. A Defensoria Pública na construção do Estado de Justiça. Revista de Direito da Defensoria Pública, Rio de Janeiro, ano VI, n07, 1995.

MOREIRA, José Carlos Barbosa. O Direito à Assistência Jurídica: Evolução no ordenamento brasileiro de nosso tempo. Revista da Academia Brasileira de Letras Jurídicas, n.3, ano VI, Rio de Janeiro: Renovar, 1992.

NERY JR., Nelson. Princípios do Processo Civil na Constituição Federal. 5. ed. São Paulo: Revista dos Tribunais, 2005.

OLIVEIRA, Maria Beatriz Bogado Bastos de. A Defensoria Pública como garantia de acesso à justiça. Revista da Defensoria Pública do Rio de Janeiro, n.16, ano 12: Rio de Janeiro, 2000. 
BARROS, Renata Furtado; MACHADO, José Alberto Oliveira de Paula. Da autonomia a universalização do acesso à justiça: a narrativa da Defensoria Pública pelas Emendas Constitucionais. Revista Eletrônica Direito e Política, Programa de Pós-Graduação Stricto Sensu em Ciência Jurídica da UNIVALI, Itajaí, v.13, n.1, $1^{\circ}$ quadrimestre de 2018. Disponível em: www.univali.br/direitoepolitica - ISSN 1980-7791

PACTO INTERNACIONAL DE DIREITOS CIVIS E POLÍTICOS. 1966. Disponível em: < http://www.planalto.gov.br/ccivil_03/decreto/19901994/d0592.htm>. Acesso em: 20 abr. 2017.

SANTOS, Boaventura de Sousa. Pela mão de Alice - o social e o político na pós-modernidade. 5a ed. São Paulo: Cortez, 1999.

SEN, Amartya. Desenvolvimento como liberdade. São Paulo: Companhia das Letras, 2000.

SIQUEIRA CASTRO, Carlos Roberto de. A Constituição e a Defensoria Pública. Revista de Direito da Defensoria Pública do Estado do Rio de Janeiro. Rio de Janeiro, Ano V, n o6, 1992.

Submetido em: 03/07/2017

Aprovado em: 11/07/2017 